\title{
4. THE BYZANTINE ICON HERMENEIA
}

\begin{abstract}
Alina Viorela Mocanu ${ }^{203}$
Abstract: In the context of the flagrant mistakes that are encountered in ecclesiastical painting and the lack of basic knowledge in this field, this study comes to present how Hermeneia has evolved throughout history. Starting from the Byzantine period, passing through the postByzantine period and reaching to the present day, Hermeneia and her predecessors, manuscripts and sketchbooks, aimed to help and maintain a canonical-artistic-ecclesial unity throughout the Orthodox Christian area. Another aspect of the article presents some ways of approaching Hermeneia from various points of view: technical, iconographic-illustrative, compositional, academic and theological. Throughout history, Hermeneia has been synthesized and structured in such a way as to provide a maximum of information but its volume should not be difficult to use by iconographers.
\end{abstract}

Key words: Hermeneia, Byzantine, art, manuscript, izvod

\section{Introduction}

The notion of Byzantine Art has been used extensively and there have not always been convergent views on how to approach its content. Conceptually speaking, we could say that its permanence over time is remarkable, although there were diversities and variations, the essence remained intact. The term Byzantine, originally used with pejorative connotations and even by the inhabitants of Constantinople, when they brought into question the Greek pagans of the ancient colonies (Byzantion), became the essence of the entire Eastern Christian Church. Byzantine art has a development on two levels. The first takes place horizontally and is the one related to Christian ecumenism, and the second is the one that transcends vertically to the Creator. The two plans embody the Deity and integrate it into our lives, giving it the possibility of Byzantine art to follow its organic and natural course in history, from Paleo-Christian art to the present day.

We cannot omit an eminently important fact, namely that the decisionmakers in the Byzantine world conceptualized, problematized and determined the situation of art, following decisions within the Ecumenical Councils, resulting from this, later, in the post-Byzantine period, a series of Hermeneias. These aimed at guiding and maintaining control and the form of canonical-artisticecclesial integrity, throughout the territory. One of the most important Synods was the Seventh Ecumenical Synod [9], at Nicaea, 787 and aimed to correct the iconoclastic heresy, begun before the reign of Emperor Leo III (717 - 741).

\footnotetext{
203 Candidate Doctoral, Free International University from Chișinău, Republic of Moldavia, email:
} aspasia_86@yahoo.com 


\section{Genetic-evolutionary paradigms}

From the etymological point of view, the word erminie means: explanation, comment, interpretation [1]. If we look at the multiple valences that ermine has as a whole, they branch out spiritually, but also artistically. The icon must include both the spiritual-dogmatic and cultico-symbolic part but also the artistic-plastic and stylistic-technical part. In essence, Hermeneia can be seen as a guide or manual of good practices in church painting.

In the Eastern Christian area, the Hermeneias were quickly integrated by painters and kept their place in church sites, being found there even now, today. This cannot be said about the West. There, Byzantine art and tradition were forgotten and gradually disappeared, with the transition from the robust Romanesque style to the supple Gothic style. These happened until the beginning of the Renaissance, when the West appropriates and assumes the consequences resulting from the Great Schism (1054) and develops its own path in the field of ecclesial art and beyond.

Exposing the problem in such a way, we understand the huge discovery that was, for the Western side, the (re)finding of the Byzantine Hermeneia in the form of manuscripts that were still used in painting sites in Orthodox churches. Almost 200 years ago, in 1828, some paintings were executed in the Greek Chapel in Munich, by Euthymios Dimitri, a Peloponnesian painter. On this occasion, he was signaled for the first time the existence of such a manuscript detailing the realization of Byzantine painting. The painter used the annotations and indications he had in a manuscript to create and make the painting. This was, in essence, a mini personal icon-library, we could say, which contained images dating from 1714. This alphabet of the icon aroused interest from German scholars, who studied it together with other fragments.

As this discovery did not have considerable reverberations, it spread especially in small environments and strictly in specialized magazines, most consider that the moment that marks the (re)discovery of Byzantine Hermeneia and its spread in the collective mentality, mass, accessible to those who they have no specialized knowledge, it was a few years later, in 1839, in France [8, 142]. Due to art historian and archaeologist Adolphe Napoleon Didron. In 1839, while Didron was on a study visit to Athos [3], he had the opportunity to see how the painting was made from the porch of the Esfigmenu monastery. Surprised by the occupation with which the painter was accustomed, he wanted to find out the mystery that made him execute biblical scenes of an impressive complexity, in record time. Joash, the painter monk, showed him the manuscript:an «interpretation of the painting», which the painter used to organize his distribution of the iconographic scenes.

That manuscript contained the iconographic «recipe» that allowed a person from the West to access Christian, Byzantine ecumenism. Later, he tries to get a manuscript from the painters Agapie and Macarie, but the attempt fails. They could not have continued their work without their manuscripts. Finally, Didron ordered a copy of one of the most complete manuscripts, by the painter Macarie. After the copy is made, it is sent to France, where it is translated and published in 
$1845[8,142]$. Arousing interest in the subject and being successful, the book is translated from a manuscript into Greek and German. It could be said that this translation, from 1855, into German was even more precise and made more accurately than the French one. After twelve years, a translation appears, but only partially, in English [2].

There was also interest in the Hermeneias in Russia, and this was manifested by Archimandrite Porphyry Uspensky, who synthesized through diligent research of existing books in various archives and libraries in the East and the Holy Mountain several manuscripts [6]. He published translations of Greek manuscripts, as well as a text of a Serbian Hermeneian manuscript. This fact highlighted what was already to be expected, namely the diversity of forms under which all these Hermeneias were found. A Russian art historian named Nikodim Pavlovich Kondakov, who was an expert on Russian Christian icons, took the initiative to publish the Byzantine Hermeneia in three volumes, but only partially succeeded in carrying out the project. Based on these invaluable contributions, but also on his own research, Athanasios Aapadopulos Kerameus, a Greek scholar, was able to design a compendium in which he synthesized the main versions of the Hermeneias and published them in 1900 and 1909. The last version published by it is still considered today as the final, reference version.

\section{Hermeneia's evolutionary trajectory in Romania}

There were, of course, concerns on the part of Romanian scholars to make translations, to edit manuscripts or to prepare specialized works on this subject. Ignoring those who only copied a manuscript, or who made a mix of several Hermeneias, which could have been done by anyone who was literate, at that time, that is more than 200 years ago. In 1805, the foundations of a new tradition were laid, with the help of Archimandrite Macarie from the Căldărușani Monastery, who translated the manuscript of the hermitage of Dionysius from Furna [4]. Archimandrite Macarius was not a painter, and yet because of the demands of the time and the acute need for guidance in the painting of holy places, he was forced to translate this manuscript. Along with him, the intervention of other high prelates was also felt, among which we mention Ghenadie Enăceanu, Melchisedec Ștefănescu and even Miron Cristea, the one who became patriarch and who was also the author of an Iconography.

Towards the end of the 19th century and the beginning of the 20th century, this interest in ermine began to be manifested among lay scholars. In this sense, we could mention Nicolae Iorga, Mihail Kogălniceanu, Alexandru Tzigara Samurcaş, Ștefan Berechet and later - Olga Greceanu. We can also mention Professor S. Mureșianu and the Handbook of Iconography that he publishes, for use by students of Fine Arts and those of Architecture. At the same time, we could mention the painter C. Petrescu. He descended from a family of Wallachian painters, artists with antiquity, fame and tradition. He tries to update the church art, to chisel it, publishing in this sense a book in French and Romanian, about fresco. 
The problem of an exposition on the firmament, in the true sense of the word, cannot be raised for the Romanian school, when it comes to the approach, study and editing of the Byzantine Hermeneia, until after the First World War. The one who made possible this statement of the Romanian school is professor Vasile Grecu [7]. If we can say that the first edition of Hermeneia exists thanks to Papadopoulos Kerameus, V. Grecu is credited with being the scholar who laid the foundations of an important step taken to establish a tradition of the manuscripts of the Byzantine Hermeneia. Undeniable in this direction is the list of studies and books that have been dedicated to Hermeneia ${ }^{204}$.

In my opinion, Books of Byzantine church painting, written by Vasile Grecu, represent the leading book, which could not yet be dethroned from the forefront of the specialized bibliography. There is still research, studies and works that are carried out on certain issues in the vast content of the ermine of painting, where topics are addressed that refer to model notebooks, to the approach of iconographic programs, to the approach of the icon from a conceptual and illustrative point of view. Here we could refer to the doctoral thesis of Robu A. Hermeneia as a historical source [10], but also to the dissertation of Mateusz Jacek Ferens - Dionysius of Fourna: Artistic Identity Through Visual Rhetoric [5].

\section{Canonical-ecclesiastical and technical-illustrative aspects pursued in ermine}

In Hermeneia, several essential aspects are pursued, among which, the compositional organization of the themes and the iconographic program, with the observance of the norms and indications from the Church. Under these conditions, the content of the ermine could be composed in a synthetic way, following the logical principles. This was systematized in a didactic approach by Professor Mureșianu and from the point of view of the Church by Miron Cristea, but it was achieved by Ene Braniște, due to his double quality, that of professor of theology but also member of Church Painting Commission.

A way of approaching Hermeneia's pragmatic approach, brings into discussion the aspects related to the technical part of a painting site: recipes for primers, laboratory and workshop procedures, tools and instruments used, substances, etc. All these are necessary and of great relevance for the painter, but also for those who will be called in the future to restore and preserve for posterity icons, frescoes, fragments of frescoes and other movable and immovable goods that have been made in a certain period of time and space because only by knowing the techniques used, a restorer can intervene on a piece by restoring its original appearance, without compromising the piece irretrievably.

In addition to this approach, comes the iconographic-illustrative part, which has largely the same interests of respecting the tradition he inherited from old

\footnotetext{
${ }^{204}$ We mention here some of the books written by Vasile Grecu: From the beauties of our great churches, Chernivtsi: The Voice of Bucovina Calendar, VIII, 1927. From the painting of our old churches, Chernivtsi: Literary Junimea, XIV, Chernivtsi, 1925. Byzantine church painting books Chernivtsi: Candela, 1934. The Romanian versions of the Byzantine Painting Hermitages, Chernivtsi: The Forest of the Cosminus, 1924. The Byzantine Painting Hermitages, Chernivtsi: Candela, 1942
} 
repertoires, drawings, sketches, sketches, sources and up to an impressive number of art albums, which constantly addresses the reference to tradition and famous painters, to those who created the school that the Hermeneias invoke with a high frequency. For this reason we can mention the way the sources were transmitted from one workshop to another or from one site to another as well as the constant editing of notebooks with iconographic models. It is important to mention that the circulation of sources from one painter to another had as an effect a stylisticaesthetic unity.

We can also look at the Hermeneia from an academic point of view, focusing on the historical-philological part. This aspect is one that obviously addresses a much smaller audience and here we can refer to the works of V. Grecu $[10,11]$. These have been intensely cited in specialized academic circles both in the country and abroad. It is undeniable that the historical-philological path is not one without limits. They stem from the very tradition of manuscripts that are not just simple copies that can lead to a common pattern but are a mix of personal experiences and creativity that collectively belong to the painters' guild. Another and last approach to ermine is the theological. Here you can follow both the historical part, Byzantium - Byzantinology or on a systematic niche Iconology, or from a practical point of view - Iconographic or biblical program. Using the means at our disposal we can conduct research that is directed mainly on the iconographic aspect and less on the aspect related to techniques and sources.

\section{Conclusions}

A desideratum related to the field of nostalgia, is still under discussion. We would like a complete edition of Hermeneia to appear, a critical and exhaustive edition, covering all the manuscripts and addressing the issues raised by these learning alphabets on the mystery of painting. If such a goal were to be achieved, it would encompass the whole of the Byzantine world. Therefore, in order for the phenomenon to be studied, it should be treated from a hermeneutical point of view and this involves hard and large-scale work that is difficult to conceptualize, but also more difficult to perform.

When considering the wishes of church painters, it is undeniable that they need quality, not quantity. Which means merging a vast volume of information in a minimum of space, creating a book that is both useful and indispensable on a construction site. In this sense, many painters who were also authors of the Hermeneias grouped and synthesized the Hermeneias and created practical and accessible editions, which later had the approval of the Holy Synod.

The latest edition of Hermeneia, by the painter Alexandru Sandulescu Verna, which we could say is one of the most complete and of maximum utility, meets all the aspects mentioned above. The author managed to gather extraordinarily ingenious, iconographic and handicraft information from various manuscripts and editions of Hermeneia, to which he added rich illustrations of icons and murals, for an eloquent example. Finally, we can say that Hermeneia is a complete and homogeneous alphabet of church painting. It was created in the post-Byzantine 
period with materials, information and traditions transmitted both orally but also in manuscripts collected since the tenth century, out of the need to facilitate the work of painters and maintain an artistic and canonical uniformity. Its importance makes it necessary to know the aspects that led to the appearance of this leading book of church painting, which is an expression that validates the canonical aspect of ecclesial art.

\section{References}

1. Dictionarul explicativ al limbii române. București: Editura Univers Enciclopedic, 1998. ISBN: 978-973-9243-29-2

2. DIDRON A. N. Christian Iconography; or, the History of Christian Art in the Middle Ages, Vol. II. London: Margaret Stokes, 1886. pp. 265-399

3. DIDRON A. N. Manuel d'Iconographie Chrétienne Grecque et Latine. Trans. Paul Durand. Paris: Imprimerie Royale, 1845. ISBN-10: 0353801259

4. DIONYSIOS OF FOURNA. Hermēneia tēs zōgraphikēs technēs. Atena: Editura Holy Koutloumousiano, 2007. ISBN 9789608986404

10=5. FERENS M. J. A. Dionysius of Fourna: Artistic Identity Through Visual Rhetoric: thesis of master degree. University of California, 2015

6. GEROL'D I. VZDORNOV. The History of the Discovery and Study of Russian Medieval Painting. Leiden: Koninklijke Brill, 2018. ISBN-10: 9004279679

7. GRECU V., DIONYSIUS of Fourna, Cărţi de pictură bisericească bizantină. Introducere critică a versiunilor românești atât după redacţiunea lui Dionisie din Furna tradusă la 1805 de arhimandritul Macarie cât şi după alte redacţiuni mai vechi traduceri anonime. Cernăuți: Tiparul Glasul Bucovinei, 1936

8. KISSIS S. C. Bayern und Byzanz: zum romantischen Byzantinismus deutscher Künstler im 19. Jahrhundert, 2002 // Veröffentlichungen zur spätantiken Archäologie und byzantinischen Kunstgeschichte, Vol. 3, 2002. pp. 125-163

9. LOUTH A., CASIDAY A. Byzantine orthodoxies: papers from the thirty-sixth Spring Symposium of Byzantine Studies, University of Durham, 23-25 March 2002. Aldershot: Ashgate, 2017. ISBN-10: 0754654966

10. ROBU A. Erminiile ca Izvor Istoric: rezumat teză de doctor, Institutul de Istorie «George Bariţiu». Cluj-Napoca, 2012

11. Jabinschi I. Imaginea Scării în pictura bisericească medievală din Moldova (Image of Stairs in the medieval church painting from Moldova) // Studiul artelor și culturlogie: istorie, teorie, practică. 2017, nr.2 (31). pp. 141-148. ISSN 23451408 